Original Research

\title{
Varied Responses of Growth and Mineral Elements Concentrations in Pennisetum ericanum and Festuca arundinacea under $\mathrm{Cd} / \mathrm{Cu}$ Addition
}

\author{
Hong Sun¹, Yulong Zheng', Yixiao Xie ${ }^{1}$, Yanli Lin², Fuyu Yang1* \\ ${ }^{1}$ Department of Grassland Science, College of Animal Science and Technology, \\ China Agricultural University, Beijing, China \\ ${ }^{2}$ Beijing Sure Academy of Biosciences, Beijing, China
}

Received: 17 October 2017

Accepted: 23 December 2017

\begin{abstract}
An experiment was carried out to compare cadmium and copper absorption and mineral nutrition accumulation in pennisetum and tall fescue in order to select an appropriate grass to remediate $\mathrm{Cd} / \mathrm{Cu}$-contaminated soil and explore their detoxification mechanisms of contamination by mineral elements. The biomass remained constant in tall fescue under each $\mathrm{Cd}$ addition level and increased in pennisetum until $\mathrm{Cu}$ reached $500 \mu \mathrm{M}$, whereas they dramatically decreased as the $\mathrm{Cu}$ or Cd solution increased, which was concurrent with quadratic regression model analysis. The $\mathrm{Cd} / \mathrm{Cu}$ concentrations in tall fescue were mostly accumulated in the roots and were much higher than those in pennisetum. The extracted amount of $\mathrm{Cd}$ in the shoots and the total $\mathrm{Cu}$ concentrations of pennisetum were higher than the corresponding values in tall fescue at every $\mathrm{Cd} / \mathrm{Cu}$ addition level. Negative correlations were observed between $\mathrm{Cd}$ and shoot $\mathrm{Ca}, \mathrm{Cu}, \mathrm{K}, \mathrm{Mg}$, and $\mathrm{Zn}$, and root $\mathrm{Cu}$ and $\mathrm{Na}$ of tall fescue and the root $\mathrm{K}$ of pennisetum. The $\mathrm{Cu}$ concentration was negatively correlated with $\mathrm{K}$ and positively correlated with $\mathrm{Na}$ in tall fescue and pennisetum under the $\mathrm{Cu}$ treatments. As the $\mathrm{Cd} / \mathrm{Cu}$ concentration in solution increased, $\mathrm{K} / \mathrm{Na}$ values were significantly decreased in the roots of tall fescue under $\mathrm{Cu}$ stress and pennisetum under $\mathrm{Cd} / \mathrm{Cu}$ stress, whereas they increased in the roots of tall fescue under $\mathrm{Cd}$ addition. In summary, pennisetum exhibited the greater biomass and $\mathrm{Cd} / \mathrm{Cu}$ extraction; indicating it as a candidate energy grass for phytoextraction. The adjustment capacity of grass for $\mathrm{K}$ and Na might relate to the tolerance to $\mathrm{Cd} / \mathrm{Cu}$.
\end{abstract}

Keywords: cadmium, copper, bioenergy grass, translocation factor, mineral element

*e-mail: yfycau@163.com 


\section{Introduction}

Due to changes in the natural environment and human activities, such as metallurgical, petrochemical, agricultural, and mining activities, as well as urban sewage, heavy metal pollution has become a major problem in terms of environmental safety and human health [1-2]. Compared with other contaminants, $\mathrm{Cd}$ and $\mathrm{Cu}$ are easily bioaccumulated with little decomposition, which is harmful to both the soil and organisms. $\mathrm{Cd}$, one of the most toxic heavy metals, can seriously damage plant metabolism, even in trace amounts [3]. Although $\mathrm{Cu}$ is a necessary element for plants, it will disturb the balance of the plant antioxidant defense system, and excessive amounts can influence photosynthesis [4]. Therefore, it is urgent to remediate $\mathrm{Cd}$ - and $\mathrm{Cu}$-polluted soil in order to protect plants, animals, and humans from health risks.

Various technological solutions, including physical methods such as electro-osmosis, soil fracturing, and thermal decomposition have been applied to remediate contaminated soils; however, these methods are cumbersome and expensive [5-6]. Additionally, chemical methods such as coagulation-flocculation, oxidation, chemical precipitation, ion exchange, adsorption, and membrane filtration can lead to secondary pollution [7]. Compared with chemical and physical methods, phytoremediation, defined as the utilization of plants to remove or accumulate soil contaminants, is a cost-effective and environmentally safe technique. Phytoremediation has become popular in the past two decades as researchers have found plants with different accumulation capacities for different metal species [7-10]. However, the slow growth rate and lower biomass become limiting factors for hyperaccumulator utilization. Bioenergy grasses grow quickly and have higher biomass than other grasses, enormous root structures, and strong tolerance to marginal lands [11-12], which are in accordance with the suggestion by Valipour and Ahn [13] for plant species suitable for phytoremediation. Their huge biomass compensated for lower accumulating contaminants in plants and produced biomass for fiber without the conflict with food crops avoiding contaminant entry into the food chain [14-15].

Pennisetum has been reported to have strong tolerance to heavy metals and accumulate $\mathrm{Cd}$ and $\mathrm{Zn}$ in its shoots, suggesting its potential to serve as a $\mathrm{Cd}$ and Zn phytoremediation plant [16-17]. Previous studies have focused on contrasting the phytoremediation ability of one or two species of energy grasses under stress from one $(\mathrm{Cd})$ or various contaminant species $(\mathrm{Zn}, \mathrm{Cr}, \mathrm{Cu}$, $\mathrm{Pb}$ and $\mathrm{Cd}$ ); however, few studies have been designed to compare bioenergy grass with other grasses having strong $\mathrm{Cd}$ stabilization ability, despite the potential of these studies to be more persuasive. Thus, tall fescue, which was reported to have strong tolerance to $\mathrm{Cd}$ and $\mathrm{Pb}$ stress and to stabilize most heavy metals in its root without any poisoning phenomena, was selected in this experiment [18-20]. Comparing the $\mathrm{Cd} / \mathrm{Cu}$ accumulation concentrations in these two plants was considered more suitable for highlighting the advantage of bioenergy grass with respect to biomass and broad heavy metal adaptability.

The absorption of heavy metals has a competitive or synergistic effect with mineral nutrition, which could disturb various physiological and biochemical activities in plants. Cd has no known biological function in plants and enters through only divalent metal ion channels $\left(\mathrm{Ca}^{2+}, \mathrm{Mg}^{2+}\right)$ or as cation transporters $\left(\mathrm{Zn}^{2+}, \mathrm{Cu}^{2+}\right.$ or $\left.\mathrm{Fe}^{2+}\right)$ [21-22]. Within plants, Cd then impacts plant nutrition absorption and disturbs the inner ionic equilibrium [23]. Many reports have examined the relationships between $\mathrm{Cd}$ and mineral elements, showing that $\mathrm{Cd}$ affected $\mathrm{Ca}$, $\mathrm{K}, \mathrm{P}, \mathrm{Mg}$, and $\mathrm{Fe}$ absorption; however, there are still no final conclusions. Plants have evolved sophisticated and tightly regulated homeostatic networks that control $\mathrm{Cu}$ uptake and delivery to target proteins and detoxification processes, as reported by Peñarrubia et al. [24]. Nevertheless, studies on the effect of excess $\mathrm{Cu}$ on mineral element accumulation are scarce. Furthermore, to screen for plants suitable for heavy metal phytoremediation, the selective absorption ability of $\mathrm{Cd} / \mathrm{Cu}$ regulated by mineral elements in different plant species should be examined. Because some researchers have found that halophyte species display specific adaptations to $\mathrm{Cd}$ stress, the phytoremediation ability of halophyte has drawn more attention [2527]. Researchers have noticed the characteristics of osmotic adjustment capacity by nontoxic organics, such as proline, soluble sugar, and soluble protein in nonhalophytes under Cd toxicity [28-29]; however, it is unknown whether the heavy metal tolerance was related to inorganic ions such as $\mathrm{K}$ and $\mathrm{Na}$ in non-halophyte plants. Thus, comparing the characteristics of nutritional element absorption, especially $\mathrm{K}$ and $\mathrm{Na}$, under $\mathrm{Cd} / \mathrm{Cu}$ stress would be helpful for determining the alleviation mechanism of heavy metal toxicity in selected plants.

Therefore, the objectives of this study are to compare the $\mathrm{Cd}$ and $\mathrm{Cu}$ adaptation and accumulation traits in pennisetum (P) and tall fescue (F) during the seedling stage, to demonstrate which of pennisetum or tall fescue has higher $\mathrm{Cd} / \mathrm{Cu}$ tolerance and absorption, and to provide support and academic evidence for the further utilization of bioenergy grasses in contaminated areas. In addition, we attempt to explain the detoxification mechanism by contrasting the differences in nutritional element absorption.

\section{Materials and Methods}

\section{Experimental Design}

Hydroponic culture was designed for this experiment to exclude the different absorption, mobility, and retention characteristics of the metal and nutrition elements in soil. The experiment was conducted in 
a greenhouse at China Agricultural University. Two species of grasses were selected: a tall fescue (Festuca arundinacea Schreb.) cultivar named "Escalade" and pennisetum (Pennisetum americanum (L.) Schum). These grasses were provided by the Grass Seed Quality Inspection Center of China Agricultural University. $\mathrm{Cd}$ was evaluated at 4 levels with three replications: $\mathrm{Cd}(0,5,20,100 \mu \mathrm{M})$; and $\mathrm{Cu}$ is a necessary element for plant growth, so the lowest level was added as $0.25 \mu \mathrm{M}$ of $1 / 2$-strength Hoagland nutrient solution as control check $(\mathrm{CK})$, hence $\mathrm{Cu}$ concentration was set as 4 level (CK, 50, 200, $500 \mu \mathrm{M})$.

\section{Plant Materials and Growth Conditions}

Seeds of tall fescue cultivar and pennisetum were immersed in an $\mathrm{H}_{2} \mathrm{O}_{2}$ solution for 20 minutes, rinsed thoroughly with tap water, and then washed with deionized water three times. Then the seeds were sown in plastic pots filled with silica sand. The pots were placed in sunlight and stored at room temperature. The pots were watered once daily to keep the sand humidified until germination, and then the plants were watered twice. Fifteen days later, five seedlings with a strip of sponge were rolled up and fastened to a polystyrene plank and transferred to plastic containers. Each container was filled with 2 L 1/2-strength Hoagland nutrient solution. Each container housed five seedlings for each treatment. In total, 48 pots were placed in the China Agricultural University greenhouse at $20 / 28^{\circ} \mathrm{C}$. The nutrient solution was changed once every three days. Before $\mathrm{Cd}$ treatment, the seedlings were grown in nutrient solution for 4 weeks. The Cd-treated plants were harvested after $\mathrm{Cd}$ treatment for 3 weeks. The $\mathrm{Cu}$ were added in solution as follows: $\mathrm{Cu}\left(\mathrm{SO}_{4}\right) \cdot 5 \mathrm{H}_{2} \mathrm{O}$ at 4 levels of $\mathrm{CK}, 50,200$, and $500 \mu \mathrm{M}$, respectively. The temperature conditions and nutrition solution were the same as for $\mathrm{Cd}$ addition. The seedlings of tall fescue and pennisetum were grown for 6 weeks in solution before $\mathrm{Cu}$ treatment. The $\mathrm{Cu}$-treated plants were harvested after $\mathrm{Cu}$ treatment for 3 weeks.

\section{Mineral Element Analysis}

The aboveground parts were cut using scissors, and the roots were washed with tap water, immersed in deionized water three times, and then dried using absorbent paper. Then the above- and below-ground plant parts were placed in an oven at $65^{\circ} \mathrm{C}$ for 48 hours and then weighed. The final biomass data are shown for the six plants per pot. The dried materials were milled $(<0.5 \mathrm{~mm})$ and digested by $\mathrm{HNO}_{3}$ and $\mathrm{H}_{2} \mathrm{O}_{2}$ $(3: 1 \mathrm{v} / \mathrm{v})$ in a microwave-accelerated reaction system (MarsX; CEM) under a three-step digestion process. The cadmium $(\mathrm{Cd})$, copper $(\mathrm{Cu})$, calcium $(\mathrm{Ca})$, potassium $(\mathrm{K})$, magnesium $(\mathrm{Mg})$, phosphorus $(\mathrm{P})$, iron $(\mathrm{Fe})$, sodium $(\mathrm{Na})$, and zinc $(\mathrm{Zn})$ concentrations were determined by inductively coupled plasma-mass spectrometry (ICP-MS; model 7700; Agilent Technologies). Agilent technologies standards were used to ensure the accuracy of chemical analysis.

\section{Data Analysis}

The metal concentration per plant was used to evaluate the plant $\mathrm{Cd}$ and $\mathrm{Cu}$ phytoextraction ability using the following equation [30]:

\section{Heavy metal concentration per plant $=$ metal concentration of dry pant tissue $\times$ dry biomass of per pot}

The Translocation Factor (TF) was calculated to evaluate the phytoremediation efficiency using the following equation [17]:

\section{Translocation factor $=$ metal concentration of dry plant shoot}

The $\mathrm{Cd}, \mathrm{Cu}$, and mineral element concentrations were subjected to one-way ANOVA using the least significant difference (LSD) to analyze significant differences between treatments $(\mathrm{P}<0.05)$. Correlation analyses were conducted between the $\mathrm{Cd} / \mathrm{Cu}$ and nutrition concentrations. The data were analyzed using SPSS17.0 statistics software for Macintosh (IBM).

\section{Results}

\section{Biomass}

The growth responses of the two grasses to different $\mathrm{Cd}$ and $\mathrm{Cu}$ levels are shown in Fig. 1. The shoots and
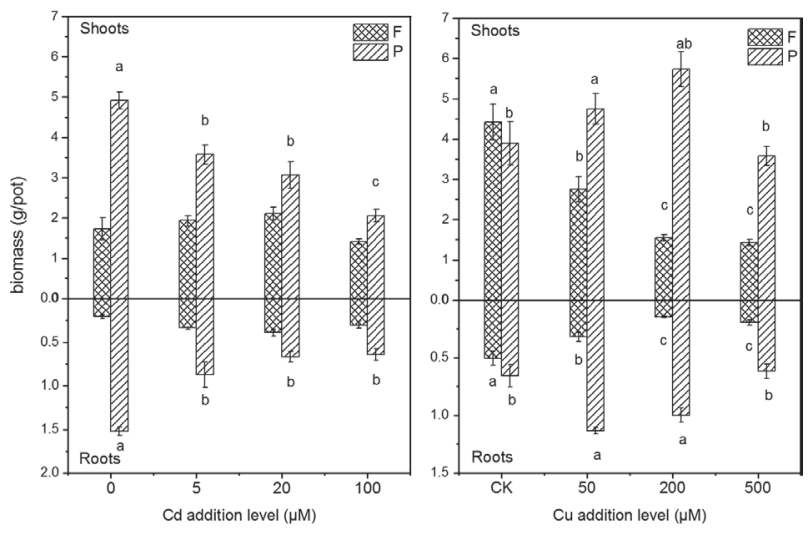

Fig. 1. Shoot and root dry biomasses of tall fescue and pennisetum under $\mathrm{Cd}$ and $\mathrm{Cu}$ treatments. $\mathrm{F}$ represent tall fescue, $\mathrm{P}$ represent pennisetum. Bars above the columns represent standard errors $(\mathrm{n}=3)$. Different letters in the bar diagram mean significantly difference at 0.05 levels under different $\mathrm{Cd}$ or $\mathrm{Cu}$ additional levels for the same plant species. It is same to the below figures and tables. 
Table 1. Linear regressions of the variables shoot and root biomass with $\mathrm{Cd}$ and $\mathrm{Cu}(\mathrm{X})$ addition levels in solution of tall fescue and pennisetum.

\begin{tabular}{|c|c|c|c|c|c|c|c|}
\hline & $\begin{array}{c}\text { Plant } \\
\text { species }\end{array}$ & & Intercept & $X$ & $X^{2}$ & Sig & $\mathrm{R}^{2}$ \\
\hline \multirow{4}{*}{$\mathrm{Cd}$} & \multirow{2}{*}{$\mathrm{F}$} & Shoot & 1.755 & 0.023 & 0.000 & 0.055 & 0.516 \\
\hline & & Root & 0.252 & 0.009 & $-8.811 \times 10^{-5}$ & 0.109 & 0.425 \\
\hline & \multirow{2}{*}{$\mathrm{P}$} & Shoot & 4.443 & -0.089 & 0.001 & 0.004 & 0.751 \\
\hline & & Root & 1.285 & -0.041 & 0.000 & 0.023 & 0.611 \\
\hline \multirow{4}{*}{$\mathrm{Cu}$} & \multirow{2}{*}{$\mathrm{F}$} & Shoot & 3.263 & -0.004 & $2.644 \times 10^{-5}$ & 0.001 & 0.822 \\
\hline & & Root & 0.463 & -0.002 & $3.716 \times 10^{-6}$ & 0.002 & 0.800 \\
\hline & \multirow{2}{*}{$\mathrm{P}$} & Shoot & 4.724 & 0.004 & $-1.342 \times 10^{-5}$ & 0.188 & 0.341 \\
\hline & & Root & 0.851 & 0.002 & $-5.289 \times 10^{-6}$ & 0.050 & 0.526 \\
\hline
\end{tabular}

F represented tall fescue, $P$ represented pennisetum (as in the following tables)

roots biomass of these grasses were significantly affected by $\mathrm{Cd}$ and $\mathrm{Cu}$ addition $(P<0.05)$, except the root biomass of pennisetum and tall fescue under $\mathrm{Cd}$ stress $(P>0.05)$. The shoots biomass of pennisetum and shoots and roots of tall fescue significantly decreased with an increase in the $\mathrm{Cd}$ and $\mathrm{Cu}$ contents in solution, respectively. Surprisingly, the biomass of tall fescue kept stable when the $\mathrm{Cd}$ concentration was below $100 \mu \mathrm{M}$, and the same trend appeared in the roots of pennisetum as the $\mathrm{Cd}$ contents in solution increased. The shoots and roots biomass of pennisetum first increased then decreased with solution $\mathrm{Cu}$ increasing.

For the 5, 20, and $100 \mu \mathrm{M} \mathrm{Cd}$ addition levels, compared with the control, the shoot biomass of pennisetum decreased by $27 \%, 38 \%$, and $58 \%$, respectively, and the root biomass of pennisetum was diminished by $43 \%, 56 \%$, and $58 \%$, respectively. Compared with the control treatment, the tall fescue shoots biomass decreased by $38 \%, 65 \%$, and $68 \%$, and the root biomass decreased by $37 \%, 71 \%$, and $61 \%$ for the low, medium, and high $\mathrm{Cu}$ addition levels, respectively. The shoot biomass of tall fescue ranged from 1.41 for $100 \mu \mathrm{M} \mathrm{Cd}$ to 2.11 for $20 \mu \mathrm{M} \mathrm{Cd}$ addition. In the case of pennisetum, the shoot biomass ranged from 3.57 for $500 \mu \mathrm{M} \mathrm{Cu}$ to 5.73 for $200 \mu \mathrm{M}$ $\mathrm{Cu}$ addition, and the root biomass ranged from 0.62 for $500 \mu \mathrm{M} \mathrm{Cu}$ to 1.13 for $50 \mu \mathrm{M} \mathrm{Cu}$ addition. The biomass data reflected that the two grasses had opposite $\mathrm{Cd} / \mathrm{Cu}$ tolerance: low and medium addition levels of $\mathrm{Cu}$ could promote pennisetum growth, whereas $\mathrm{Cd}$ had no obvious toxicity effect on tall fescue growth - even under the highest Cd addition levels.

Quadratic regression models for the shoot and root biomass of pennisetum and tall fescue under $\mathrm{Cd}$ and $\mathrm{Cu}$ addition were evaluated (Table 1). The confidence level for each model exceeded $95 \%$ (i.e., $\mathrm{P}<0.05$ ), except for the root of tall fescue under $\mathrm{Cd}$ stress and that of pennisetum under $\mathrm{Cu}$ stress. The sensitivity of the biomass to $\mathrm{Cd} / \mathrm{Cu}$ addition was shown by comparing the absolute values of the $\mathrm{X}^{2}$ coefficient estimates (Table 1). Therefore, among the shoot and root biomass, the sensitivity of tall fescue and pennisetum

Table 2. Concentrations of $\mathrm{Cd}$ and $\mathrm{Cu}$ in tall fescue and pennisetum under different $\mathrm{Cd}$ and $\mathrm{Cu}$ addition levels (mg/kg DW).

\begin{tabular}{|c|c|c|c|c|c|c|c|}
\hline \multicolumn{2}{|c}{} & \multicolumn{3}{c|}{ F } & \multicolumn{2}{c|}{ P } \\
\cline { 2 - 8 } & & Shoot & Root & TF & Shoot & Root & TF \\
\hline \multirow{3}{*}{$\mathrm{Cd}$} & 0 & $0.3 \pm 0.1 \mathrm{~d}$ & $13.7 \pm 11.9 \mathrm{~d}$ & $0.02 \mathrm{~b}$ & $1.0 \pm 0.9 \mathrm{~d}$ & $0.4 \pm 0.3 \mathrm{c}$ & $20.0 \mathrm{a}$ \\
\cline { 2 - 9 } & 5 & $55.5 \pm 5.0 \mathrm{c}$ & $896.2 \pm 47.6 \mathrm{c}$ & $0.06 \mathrm{ab}$ & $68.9 \pm 6.7 \mathrm{c}$ & $120.7 \pm 16.6 \mathrm{~b}$ & $0.57 \mathrm{~b}$ \\
\cline { 2 - 9 } & 20 & $84.4 \pm 9.3 \mathrm{~b}$ & $1060.6 \pm 149.6 \mathrm{~b}$ & $0.08 \mathrm{a}$ & $93.0 \pm 3.4 \mathrm{~b}$ & $281.2 \pm 59.2 \mathrm{~b}$ & $0.33 \mathrm{~b}$ \\
\cline { 2 - 9 } & 100 & $166.8 \pm 9.0 \mathrm{a}$ & $2471.6 \pm 171.1 \mathrm{a}$ & $0.07 \mathrm{ab}$ & $149.9 \pm 9.4 \mathrm{a}$ & $1533.6 \pm 64.7 \mathrm{a}$ & $0.12 \mathrm{c}$ \\
\hline \multirow{4}{*}{$\mathrm{Cu}$} & $\mathrm{CK}$ & $16.4 \pm 1.5 \mathrm{~d}$ & $174.4 \pm 45.0 \mathrm{~d}$ & $0.09 \mathrm{a}$ & $18.9 \pm 2.5 \mathrm{c}$ & $60.0 \pm 2.0 \mathrm{c}$ & $0.31 \mathrm{a}$ \\
\cline { 2 - 9 } & 50 & $45.1 \pm 2.5 \mathrm{c}$ & $1039.4 \pm 92.8 \mathrm{c}$ & $0.04 \mathrm{~b}$ & $33.2 \pm 0.9 \mathrm{c}$ & $868.4 \pm 96.0 \mathrm{~b}$ & $0.04 \mathrm{~b}$ \\
\cline { 2 - 9 } & 200 & $73.3 \pm 12.5 \mathrm{~b}$ & $2093.8 \pm 122.7 \mathrm{~b}$ & $0.03 \mathrm{~b}$ & $95.2 \pm 3.2 \mathrm{a}$ & $1005.6 \pm 40.0 \mathrm{~b}$ & $0.09 \mathrm{~b}$ \\
\cline { 2 - 9 } & 500 & $113.5 \pm 6.4 \mathrm{a}$ & $4123.4 \pm 236.6 \mathrm{a}$ & $0.03 \mathrm{~b}$ & $105.3 \pm 9.9 \mathrm{a}$ & $2056.9 \pm 65.6 \mathrm{a}$ & $0.05 \mathrm{~b}$ \\
\hline
\end{tabular}

Different letters in the same column represent significant differences at 0.05 level 
to Cd was as follows: tall fescue $<$ pennisetum in the shoots, and tall fescue $>$ pennisetum in the roots. The trend in the sensitivity of the shoots to $\mathrm{Cu}$ was tall fescue $>$ pennisetum, whereas the trend in the roots was the exact opposite. Moreover, the roots were less sensitive than the shoots.

\section{$\mathrm{Cd}$ and $\mathrm{Cu}$ Concentrations}

The $\mathrm{Cd}$ and $\mathrm{Cu}$ concentrations measured in the shoots and roots of tall fescue and pennisetum under different $\mathrm{Cd}$ and $\mathrm{Cu}$ addition treatments are shown in Table 2. The $\mathrm{Cd}$ and $\mathrm{Cu}$ concentrations in the shoots and roots of the two plants were significantly different among the various $\mathrm{Cd} / \mathrm{Cu}$ additional levels $(P<0.05)$ and increased as the contaminant level in the solutions increased $(P<0.05)$. The highest $\mathrm{Cd} / \mathrm{Cu}$ concentrations were observed in the tissues of tall fescue.

The shoot $\mathrm{Cd}$ concentrations in tall fescue were similar to those in pennisetum at every $\mathrm{Cd}$ addition level, and the largest $\mathrm{Cd}$ accumulation amount was $166.8 \mathrm{mg} / \mathrm{kg}$. The $\mathrm{Cd}$ concentrations in the roots of tall fescue were 1.6-7.4 times higher than those in pennisetum. The $\mathrm{Cu}$ concentrations in the aboveground part of tall fescue were higher than those in pennisetum, except for the pennisetum under $200 \mu \mathrm{M} \mathrm{Cu}$ addition, which had a $30 \%$ higher $\mathrm{Cu}$ concentration than tall fescue. However, the $\mathrm{Cu}$ concentrations in the roots of tall fescue were much higher than those in pennisetum at every $\mathrm{Cu}$ addition level. Furthermore, the root $\mathrm{Cd} / \mathrm{Cu}$ concentrations in the two grasses were substantially higher than those in the shoots. The $\mathrm{Cd}$ accumulation in the roots was on average $94 \%$ and $75 \%$ of the total concentration in tall fescue and pennisetum, respectively; the corresponding $\mathrm{Cu}$ concentration ratios in the roots were $97 \%$ and $94 \%$.

The TF was calculated to further confirm the $\mathrm{Cd} /$ $\mathrm{Cu}$ accumulation in the shoots, and all the values were less than 1, indicating that the three grasses stabilized $\mathrm{Cd} / \mathrm{Cu}$ mainly in the belowground parts. The TF of the grasses decreased as the $\mathrm{Cd} / \mathrm{Cu}$ solution concentration increased, and the highest $\mathrm{TF}$ was observed in pennisetum.

\section{Extracted $\mathrm{Cd}$ and $\mathrm{Cu}$ Concentrations}

The extracted $\mathrm{Cd}$ and $\mathrm{Cu}$ concentrations in each pot of tall fescue and pennisetum detected under different $\mathrm{Cd}$ and $\mathrm{Cu}$ additional levels are shown in Fig. 2. The extracted $\mathrm{Cd}$ and $\mathrm{Cu}$ concentrations in each pot of these grasses significantly increased as the solution $\mathrm{Cd} / \mathrm{Cu}$ concentration increased; the roots extracted $\mathrm{Cd} / \mathrm{Cu}$ concentrations were higher than the shoots concentrations under every $\mathrm{Cd} / \mathrm{Cu}$ addition level, except for the extracted $\mathrm{Cd}$ concentration in pennisetum. The total extracted $\mathrm{Cd}$ concentration in tall fescue was higher than that in pennisetum. However, the $\mathrm{Cd}$ extracted from the pennisetum shoots was higher than that extracted from tall fescue, increasing by $129 \%$, $60 \%$, and $31 \%$ under the 5,20 , and $100 \mu \mathrm{M} \mathrm{Cd}$ addition levels, respectively.
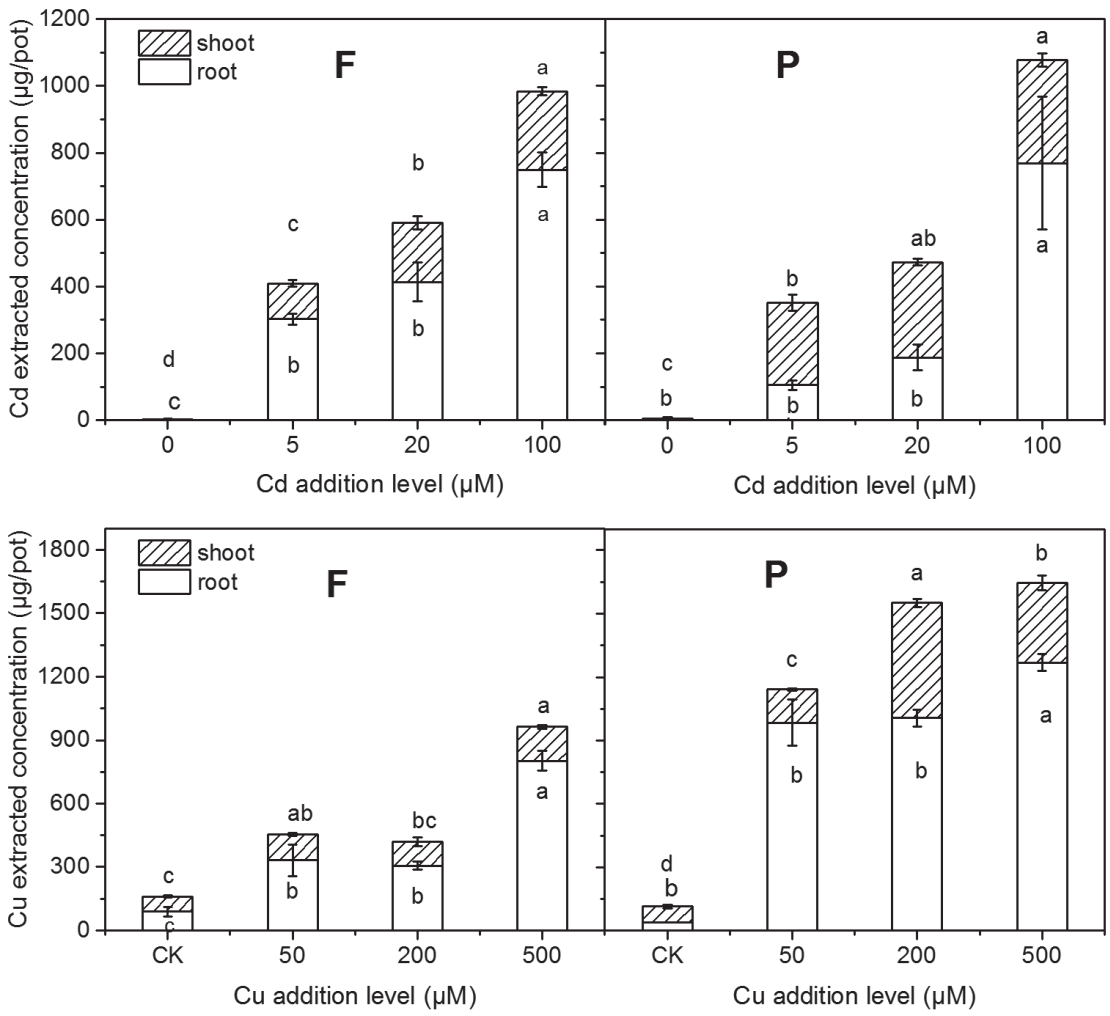

Fig. 2. Shoot and root $\mathrm{Cd} / \mathrm{Cu}$ extracted concentration of tall fescue and pennisetum under $\mathrm{Cd}$ and $\mathrm{Cu}$ treatments. 
Concentrations of Macroelements, Middleelements, and Microelements

The macroelement concentrations $(\mathrm{Ca}, \mathrm{K}, \mathrm{Mg}$, and $\mathrm{P}$ ) in tall fescue and pennisetum receiving $\mathrm{Cd} / \mathrm{Cu}$ treatments are shown in Fig. 3. In the $\mathrm{Cd}$ and $\mathrm{Cu}$ treatment, the concentrations of $\mathrm{Ca}, \mathrm{K}, \mathrm{Mg}$, and $\mathrm{P}$ significantly decreased in the shoots of tall fescue as the $\mathrm{Cd}$ concentration increased, except $\mathrm{K}$ and $\mathrm{P}$ under $\mathrm{Cd}$ treatment, and its root $\mathrm{K}$ concentrations decreased as the $\mathrm{Cu}$ content in solution increased. For pennisetum, the shoot $\mathrm{Ca}$ concentration significantly decreased as the $\mathrm{Cd}$ content in solution increased, and the same result was observed in the roots for the $\mathrm{K}$ concentration with $\mathrm{Cd}$ addition and $\mathrm{K}, \mathrm{Mg}$, and $\mathrm{P}$ concentrations with $\mathrm{Cu}$ addition. The concentrations of $\mathrm{Ca}$ and $\mathrm{P}$ in the roots
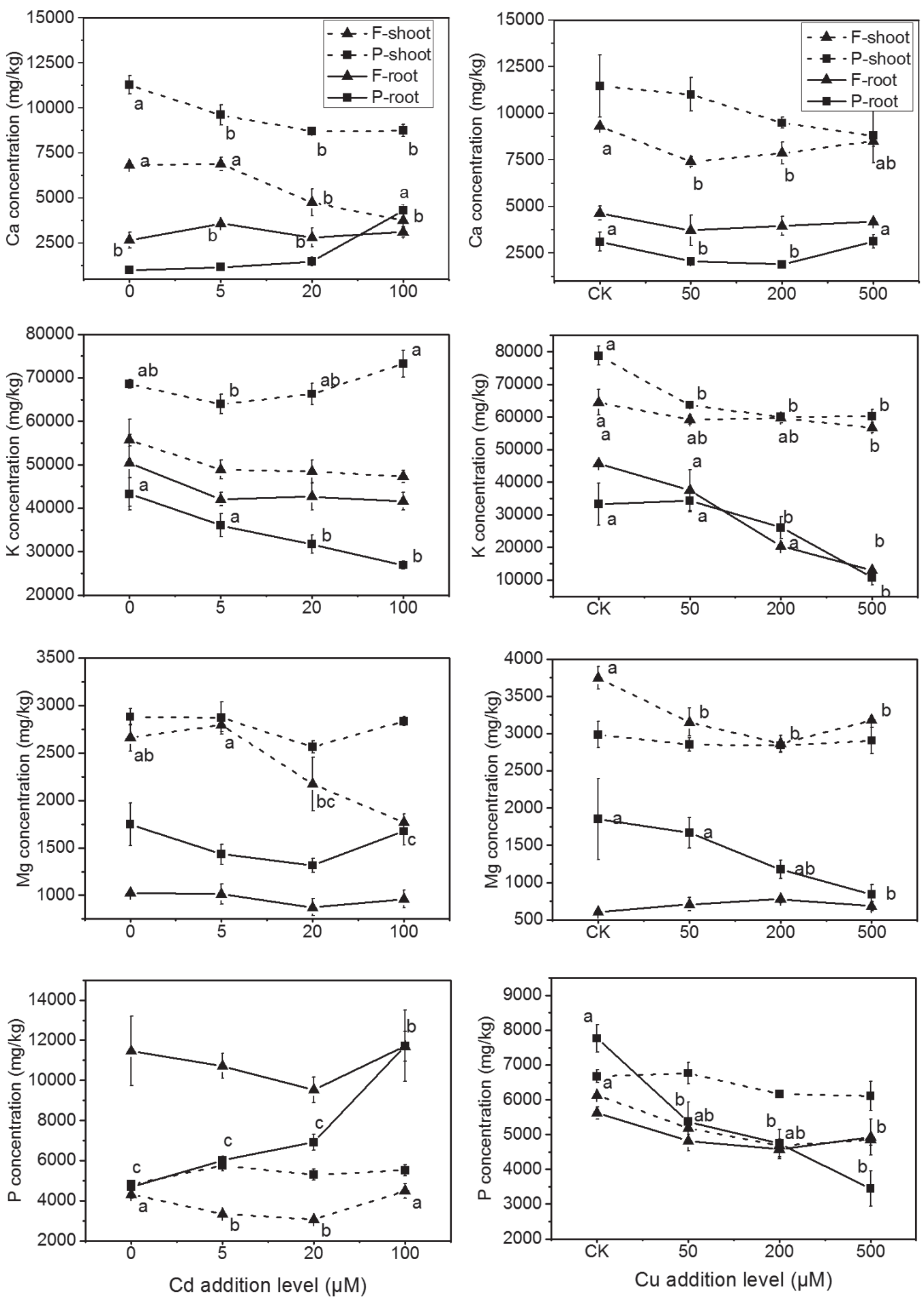

Fig. 3. The macroelement concentrations $(\mathrm{Ca}, \mathrm{K}, \mathrm{Mg}, \mathrm{P})$ in tall fescue and pennisetum under $\mathrm{Cd} / \mathrm{Cu}$ treatments. The triangle refer to tall fescue, the square refer to pennisetum; the dotted line refer to shoots and solid line refer to roots. It is same to the below figures. 
under $100 \mu \mathrm{M} \mathrm{Cd}$ addition were significantly higher than those at the other $\mathrm{Cd}$ addition levels.

The microelement concentrations (Fe, Na, Zn and $\mathrm{Cu}$ ) in tall fescue and pennisetum under $\mathrm{Cd} / \mathrm{Cu}$ treatments are shown in Fig. 4. As the solution $\mathrm{Cd} / \mathrm{Cu}$ increased, the shoot $\mathrm{Zn}$ and $\mathrm{Fe}$ concentrations in tall fescue decreased, whereas there were no significant differences in the levels of the other elements in the shoots of these two grasses. For the belowground plant parts, the $\mathrm{Fe}$ and $\mathrm{Na}$ concentrations in pennisetum with $\mathrm{Cd}$ treatment and the $\mathrm{Na}$ concentration in tall fescue and pennisetum with $\mathrm{Cu}$ treatment increased as the solution $\mathrm{Cd} / \mathrm{Cu}$ concentration increased. However, opposite trends were observed for the $\mathrm{Na}$ and $\mathrm{Zn}$ concentrations in tall fescue with $\mathrm{Cd}$ addition and the $\mathrm{Zn}$ concentration in pennisetum with $\mathrm{Cu}$ addition.

The values of $\mathrm{K} / \mathrm{Na}$ in tall fescue and pennisetum under $\mathrm{Cd} / \mathrm{Cu}$ treatments are shown in Fig. 5. These results proved to be particularly interesting. The $\mathrm{K} / \mathrm{Na}$ values in the shoots of tall fescue and
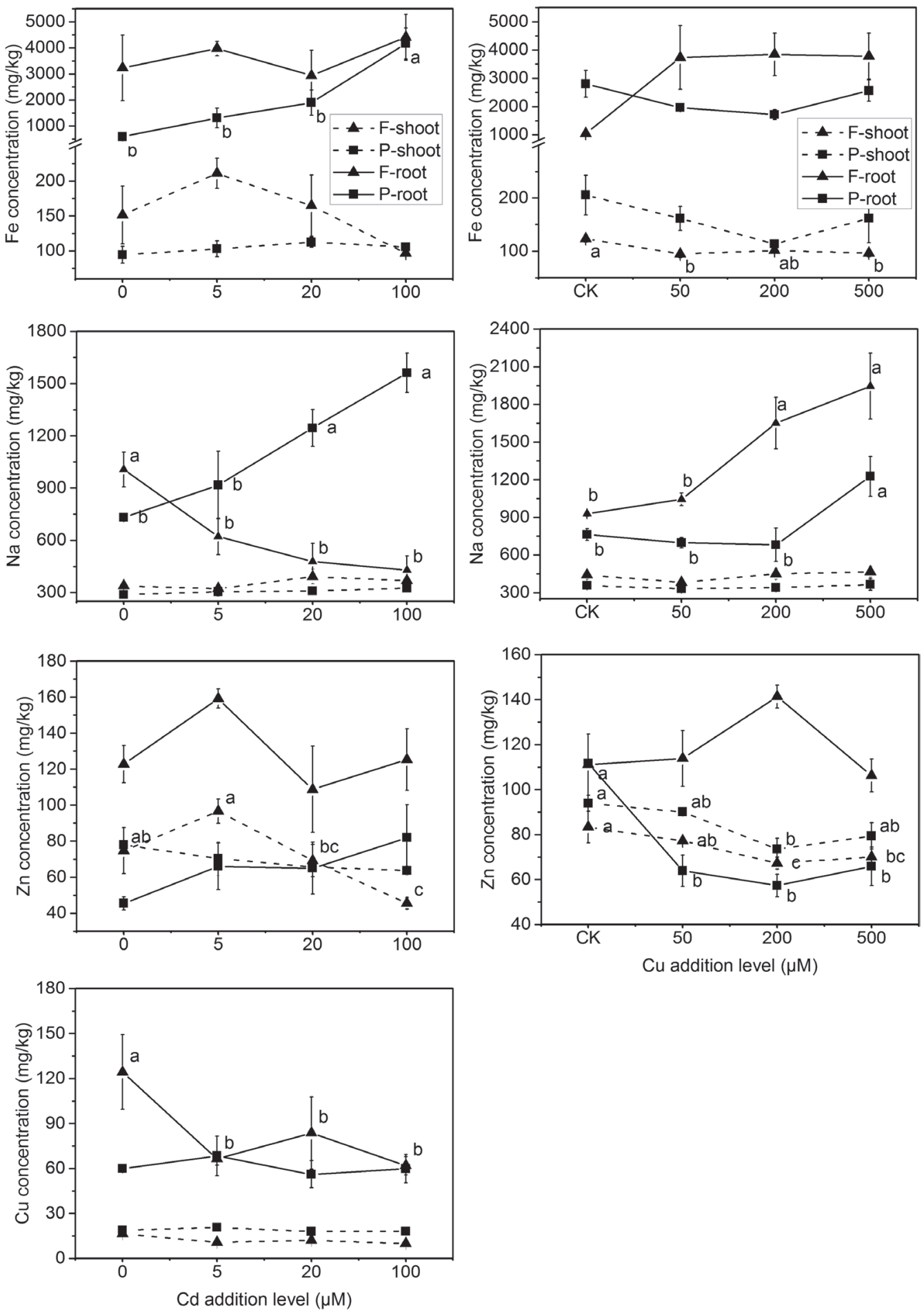

Fig. 4. The microelement concentrations $(\mathrm{Fe}, \mathrm{Na}, \mathrm{Zn}, \mathrm{Cu})$ in tall fescue and pennisetum under $\mathrm{Cd} / \mathrm{Cu}$ treatments. 

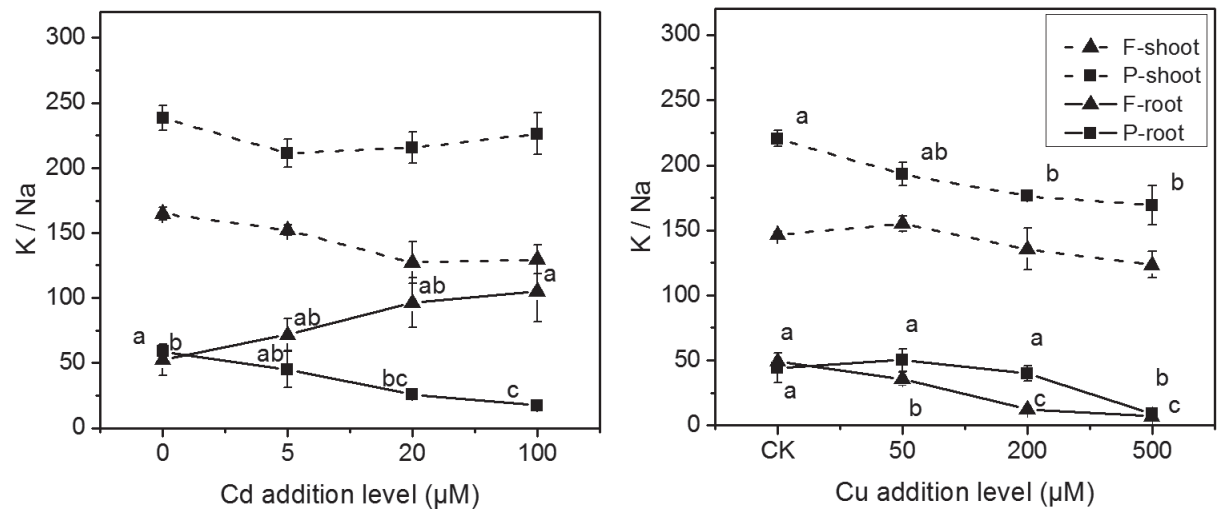

Fig. 5. The $\mathrm{K} / \mathrm{Na}$ value in tall fescue and pennisetum under $\mathrm{Cd} / \mathrm{Cu}$ treatments.

pennisetum receiving $\mathrm{Cd}$ treatment were not significantly different among the four $\mathrm{Cd}$ levels, whereas the values in the pennisetum roots decreased; by contrast, the $\mathrm{K} / \mathrm{Na}$ values in the roots of tall fescue increased with the solution $\mathrm{Cd}$ concentration. For the $\mathrm{Cu}$ treatment, the $\mathrm{K} / \mathrm{Na}$ values decreased as the addition level was increased, and this decrease was sharper in tall fescue than pennisetum.

\section{The Relationship between $\mathrm{Cd} / \mathrm{Cu}$ and Mineral Element}

The correlation between $\mathrm{Cd}$ and $\mathrm{Cu}$ and the nutritional element concentrations $(\mathrm{Ca}, \mathrm{K}, \mathrm{Mg}, \mathrm{P}, \mathrm{Fe}$, $\mathrm{Na}, \mathrm{Zn}$, and $\mathrm{Cu}$ ) and $\mathrm{K} / \mathrm{Na}$ value in the shoots and roots is shown in Table 3. In the shoots, $\mathrm{Cd}$ was negatively correlated with $\mathrm{Ca}, \mathrm{K}, \mathrm{Mg}, \mathrm{Zn}, \mathrm{Cu}$, and $\mathrm{K} / \mathrm{Na}$ in tall fescue, and negatively correlated with $\mathrm{Cd}$ in pennisetum. In the roots, $\mathrm{Cd}$ had negative relationships with $\mathrm{Na}$ and $\mathrm{Cu}$ and positive relationships with $\mathrm{K} / \mathrm{Na}$ in tall fescue, as well as negative relationships with $\mathrm{K}$ and $\mathrm{K} / \mathrm{Na}$ and significantly positive relationships with $\mathrm{Ca}, \mathrm{P}, \mathrm{Fe}, \mathrm{Na}$, and $\mathrm{Zn}$ in pennisetum. In the shoots, $\mathrm{Cu}$ was negatively correlated with $\mathrm{K}, \mathrm{Zn}$, and $\mathrm{K} / \mathrm{Na}$ in pennisetum and $\mathrm{Zn}$ in fescue. In the roots, $\mathrm{Cu}$ was positively correlated with
$\mathrm{Na}$ and negatively correlated with $\mathrm{K}, \mathrm{Mg}, \mathrm{P}$, and $\mathrm{K} / \mathrm{Na}$ in pennisetum, and negatively correlated with $\mathrm{K}$ and $\mathrm{K} / \mathrm{Na}$ and positively correlated with $\mathrm{Na}$ in fescue. All the significantly correlated relationships showed linear regressions with the $\mathrm{Cd} / \mathrm{Cu}$ concentrations in tall fescue and pennisetum.

\section{Discussion}

\section{Plant Growth}

$\mathrm{Cd}$, as the most toxic element in the soil environment, significantly inhibited plant growth. In the present study, the shoots biomass of pennisetum was higher than that of tall fescue, although it decreased with an increasing $\mathrm{Cd}$ concentration in solution. In contrast, the biomass of tall fescue exhibited no significant difference under various $\mathrm{Cd}$ stress scenarios. Pennisetum was reported as biomass decreasing at $\mathrm{Cd}$ concentrations higher than $30 \mathrm{mg} / \mathrm{kg}$ [17], and biomass-inhibiting effects were reported for other grasses like Chrysopogon Zizanioides, Lolium perenne, Panicum virgatum, and the Cd hyper-accumulator Bidens tripartite [30-31]. Tall fescue was observed to have a strong tolerance to $\mathrm{Cd}$

Table 3. Pearson correlation coefficient between $\mathrm{Cd} / \mathrm{Cu}$ and mineral element concentration of tall fescue and pennisetum.

\begin{tabular}{|c|c|c|c|c|c|c|c|c|c|c|c|}
\hline & & & $\mathrm{Ca}$ & K & $\mathrm{Mg}$ & $\mathrm{P}$ & $\mathrm{Fe}$ & $\mathrm{Na}$ & $\mathrm{Zn}$ & $\mathrm{Cu}$ & $\mathrm{K} / \mathrm{Na}$ \\
\hline & $\Gamma$ & Shoot & $-0.758 * *$ & $-0.667 *$ & $-0.700 *$ & 0.226 & -0.443 & 0.377 & $-0.606^{*}$ & $-0.736 * *$ & $-0.660 *$ \\
\hline & & Root & 0.252 & -0.437 & -0.054 & 0.289 & 0.468 & $-0.602 *$ & 0.062 & $-0.651^{*}$ & $0.633^{*}$ \\
\hline & $\mathrm{D}$ & Shoot & $-0.716^{*}$ & 0.422 & -0.055 & 0.447 & 0.329 & 0.424 & -0.465 & -0.151 & -0.112 \\
\hline & & Root & $0.956^{* *}$ & $-0.653^{*}$ & 0.197 & $0.907 * *$ & $0.951 * *$ & $0.676^{*}$ & $0.787 * *$ & 0.177 & $-0.607 *$ \\
\hline & $\Gamma$ & Shoot & 0.069 & -0.509 & -0.528 & -0.507 & -0.343 & 0.322 & $-0.619^{*}$ & I & 0.484 \\
\hline & & Root & 0.059 & $-0.896^{* *}$ & 0.176 & -0.248 & 0.433 & $0.824 * *$ & -0.005 & I & $-0.886^{* *}$ \\
\hline & $\mathrm{D}$ & Shoot & -0.475 & $-0.695^{*}$ & -0.078 & -0.563 & -0.311 & 0.221 & $-0.777 * *$ & I & $-0.789 * *$ \\
\hline & 1 & Root & 0.192 & $-0.812 * *$ & $-0.732 *$ & $-0.861^{*}$ & 0.023 & $0.668 *$ & -0.590 & I & $-0.774 * *$ \\
\hline
\end{tabular}

*The coefficient is significant at 0.05 level, ${ }^{* *}$ The coefficient is significant at 0.01 level 
under $80 \mathrm{mg} / \mathrm{kg}$ without any toxic symptoms or biomass reduction [20]. The performances of tall fescue and pennisetum under $\mathrm{Cd}$ addition were in accordance with previous studies.

$\mathrm{Cu}$ is an essential element for plant growth, as it is a component of metabolic enzymes and participates in a variety of physiological metabolic activities. Fertilization with $\mathrm{Cu}$ in the appropriate concentration range could promote plant growth, but when the concentration is over a certain range, $\mathrm{Cu}$ can induce membrane damage and destruction, change the activity of antioxidant enzymes and redox levels in the cell, and be toxic to plant development [4]. Our results verified that the biomass of pennisetum initially increased and then decreased under $\mathrm{Cu}$ addition, which was similar to the results obtained by Arduini et al. for Pinus pinea, Pinus pinaster, and Fraxinus angustifolia seedlings [32]. However, the biomass of tall fescue directly decreased when the $\mathrm{Cu}$ content in solution was more than $200 \mu \mathrm{M}$; this trend was contrary to the phenomenon observed in Cd stress.

The biomass directly reflected that tall fescue has strong tolerance to $\mathrm{Cd}$ and sensitivity to $\mathrm{Cu}$, whereas the opposite relationships regarding the tolerance/sensitivity to $\mathrm{Cd} / \mathrm{Cu}$ were detected in pennisetum. These results were in accordance with the trend in the absolute values of $\mathrm{X}^{2}$ of the quadratic regression models for the shoots of these grasses. However, the absolute values of $\mathrm{X}^{2}$ of the quadratic regression models for the roots showed the opposite relationship, which may be due to the roots, which are more sensitive to $\mathrm{Cd} / \mathrm{Cu}$ stress, coming into contact with the contaminants in solution first and being able to regulate the physiological and biochemical activity to immediately protect themselves from toxicity. Thus, the absolute values of $\mathrm{X}^{2}$ could directly reflect the tolerance to $\mathrm{Cd} / \mathrm{Cu}$ in tall fescue and pennisetum in shoots biomass, the values in root indicating root sensitivity to heavy metals for preparing in advance to fight $\mathrm{Cd} / \mathrm{Cu}$ stress.

\section{$\mathrm{Cd}$ and $\mathrm{Cu}$ Accumulation and Translocation}

The highest shoot $\mathrm{Cd}$ concentrations in tall fescue and pennisetum were 166.8 and $171 \mathrm{mg} / \mathrm{kg}$, respectively, under $100 \mu \mathrm{M} \mathrm{Cd}$ addition, whereas the shoot $\mathrm{Cu}$ concentrations of the two grasses were much lower than the criterion under all $\mathrm{Cu}$ treatments. Hence, tall fescue and pennisetum could be regarded as $\mathrm{Cd}$ hyperaccumulators in seriously Cd-polluted soils. Their root $\mathrm{Cd} / \mathrm{Cu}$ concentrations were higher than the minimum standard under all $\mathrm{Cd} / \mathrm{Cu}$ addition levels, thus suggesting that both tall fescue and pennisetum could be used as phytostabilizers for $\mathrm{Cd} / \mathrm{Cu}$-polluted soils. The results were consistent with previous reports, which found that the accumulated $\mathrm{Cd}$ concentrations in the roots of pennisetum and tall fescue were higher than those in the shoots [33-34]. Similar results were found in other studies on Arundo donax, Miscanthus sacchariflorus, and Elymus elongatus subsp. ponticus cv. Szarvasi-1 under stress from various heavy metals [35-36]. Retention of the contaminants in the plant root is regarded as a main strategy for alleviating heavy metal toxicity because roots secrete organic matter (organic acids) to chelate heavy metals or undergo acidification of the rhizosphere to promote heavy metal dissolution and absorption. Most vascular herbaceous species prefer to chelate metal ions in the root cell wall, except for hyperaccumulators, which prefer to accumulate metals in the shoots [37-38].

Although the TFs of the these grasses were lower than 1 and showed a decreasing trend as the $\mathrm{Cd} / \mathrm{Cu}$ contents in solution increased, the TFs of pennisetum from 0.11 and 0.58 were much higher than those of tall fescue and were similar to the results $(0.18-0.55)$ reported by Zhang et al. [17]. The $\mathrm{Cd} \mathrm{TF}$ of tall fescue ranged from 0.06 to 0.08 , which was lower than the results reported by $\mathrm{Xu}$, with $\mathrm{Cd} \mathrm{TF}$ values of tall fescue were 0.1 and 0.2 at 40 and $80 \mathrm{mg} / \mathrm{kg}$, respectively [20]. This finding may be caused by the different growth periods and growth substrates. The TFs of tall fescue were kept stable and lower than that of pennisetum irrespective of $\mathrm{Cd}$ additional levels, implying that pennisetum had the ability to be a promising $\mathrm{Cd}$ phytoextracted plant. In addition, the TFs of $\mathrm{Cd}$ were higher than those of $\mathrm{Cu}$ in the grasses under corresponding contaminate levels, possibly because the roots of the grasses retain more $\mathrm{Cu}$ in the root structures, such as the cell wall, or $\mathrm{Cd}$ is a stronger stimulator of transporter protein expression during the root xylem loading process [39-40]. As expected, due to the large biomass of pennisetum, which compensated the lower absolutely shoot $\mathrm{Cd}$ and $\mathrm{Cu}$ accumulated concentrations, its shoot $\mathrm{Cd}$ and $\mathrm{Cu}$ concentrations were kept similar or higher than tall fescue in each plant irrespective of the solution $\mathrm{Cd} / \mathrm{Cu}$ concentrations.

\section{$\mathrm{Na}, \mathrm{K}$, and other Mineral Elements Absorption}

In this experiment, as the $\mathrm{Cd} / \mathrm{Cu}$ solution increased, increasing trends in $\mathrm{Na}$ and decreasing trends in $\mathrm{K}$ were observed in the roots of tall fescue and pennisetum under $\mathrm{Cd} / \mathrm{Cu}$ addition, except for the roots of tall fescue under $\mathrm{Cd}$ addition. Hemelraad [41] found that in freshwater clams, $\mathrm{Cd}$ led to a dramatic decrease in $\mathrm{Na}$ during the first 2-8 weeks of the treatment period, and then the Na content stabilized declined, and K started to increase in the last four weeks. Researchers found that during ion absorption and transportation processes, $\mathrm{Na}$ could decrease $\mathrm{K}$ absorption [42], and excess Na could damage the plasma membrane, leading to $\mathrm{K}$ efflux [43]. In this study, it was inferred that $\mathrm{Cd} / \mathrm{Cu}$ had antagonistic effects with $\mathrm{Na}$ and then influenced $\mathrm{K}$ absorption. A considerable decrease in the $\mathrm{K} / \mathrm{Na}$ value, which was used as a representation of the degree of ion damage and salinity tolerance, could cause metabolic abnormality, increase plant cell membrane permeability, and decrease antioxidant enzyme activities [44-46]. With an increase in solution $\mathrm{Cd} / \mathrm{Cu}$, the root $\mathrm{K} / \mathrm{Na}$ value was observed 
to significantly decrease in this study, and the plant leaves begin to lose water and undergo chlorosis, especially under the highest $\mathrm{Cd} / \mathrm{Cu}$ stress. Hence, the unbalance between $\mathrm{K}$ and $\mathrm{Na}$ could be one of the reasons that $\mathrm{Cd}$ and $\mathrm{Cu}$ induce oxidative stress and produce reactive oxygen species [47-48]. In contrast, the $\mathrm{Na}$ concentration decreased and the $\mathrm{K}$ concentration remained stable in the roots of tall fescue under $\mathrm{Cd}$ addition; additionally, there was no competitive inhibition between $\mathrm{Na}$ and $\mathrm{K}$ or obvious poisoning phenomenon. Thus, the strong Cd tolerance mechanism of tall fescue was regulated by selectively absorbing the ions into the roots and compartmentalizing the contaminants in belowground parts to diminish their toxicity to aboveground parts, which was similar to the mechanism of plant resistance to salinity [49].

$\mathrm{Cd}$, which does not have a known biological function in plants, enters plant cells via cation channels of $\mathrm{Ca}$ and $\mathrm{Mg}$ or transporters of other divalent cations such as $\mathrm{Zn}$, $\mathrm{Cu}$, or $\mathrm{Fe}[50]$. Zhang reported that $\mathrm{Cd}$ could compete with the transporters of element ions in plants as the concentration of $\mathrm{Cd}$ in soil increases, which induces the antagonistic interaction between $\mathrm{Cd}$ and element ions [17]. In our study, $\mathrm{Cd}$ had a negative relationship with the $\mathrm{Ca}, \mathrm{Mg}, \mathrm{Zn}$, and $\mathrm{Cu}$ concentrations in the shoots of tall fescue and $\mathrm{Ca}$ in pennisetum, suggesting that $\mathrm{Cd}$ is absorbed in shoots by the $\mathrm{Ca}$ and $\mathrm{Mg}$ channels and $\mathrm{Zn}$, $\mathrm{Cu}$ carriers, which was supported by previous reports. However, positive correlations were observed between $\mathrm{Ca}, \mathrm{P}, \mathrm{Fe}, \mathrm{Na}$, and $\mathrm{Zn}$ content and $\mathrm{Cd}$ concentration in the roots of pennisetum. Combined with the lower $\mathrm{Cd}$ concentration in the roots, these results indicated that in the competition with $\mathrm{Cd}$, these elements were stronger, which inhibited $\mathrm{Cd}$ absorption [51]. In addition, $\mathrm{P}$ was found to reduce $\mathrm{Cd}$ toxicity by forming a Cd-phosphate precipitant and stimulating organic acid synthesis in roots, which reduces soil $\mathrm{Cd}$ bioavailability [52-53]. Although $\mathrm{Fe}$ nutrition mitigated $\mathrm{Cd}$ toxicity because of the competition for membrane transporters, the root $\mathrm{Cd}$ concentration of pennisetum was positively correlated with $\mathrm{Fe}$ concentration in the present study, this may due to the plants forming an iron plaque to fix and sequester $\mathrm{Cd}$ on the root surface to inhibit heavy metal absorption [54]. Plants have homeostatic mechanisms to maintain appropriate concentrations of $\mathrm{Cu}$ in different environmental conditions in order to precisely deliver it to specific compartments and to target it to metalloproteins while avoiding its toxic effects [4]. In pennisetum, the $\mathrm{Mg}, \mathrm{P}$, and $\mathrm{Zn}$ concentrations in the roots were negatively correlated with $\mathrm{Cu}$, which was similar to results from the study reported by Alva, who found that increased external $\mathrm{Cu}$ decreased the uptake of $\mathrm{Zn}, \mathrm{Fe}$, and $\mathrm{Mn}$ in citrus rootstocks [55]. Negative correlations were detected in shoots of these grasses because $\mathrm{Cu}$ and $\mathrm{Zn}$ are involved in many of the same metabolic activities. For example, they are components of metalloenzymes, which are involved in oxidationreduction processes and in protein and lignin synthesis [21].

\section{Conclusions}

Although the energy grass pennisetum had less total $\mathrm{Cd} / \mathrm{Cu}$ accumulation, the extracted $\mathrm{Cd}$ in the shoots and total $\mathrm{Cu}$ amounts were higher than those in tall fescue, suggesting that pennisetum could be a promising plant material for phytoremediation in $\mathrm{Cd} / \mathrm{Cu}$-polluted areas. Although our experiment was conducted in the seedling stage, the $\mathrm{Cd} / \mathrm{Cu}$ concentration in solution was higher than that in real-life soil conditions. Hence, the results provide convincing evidence for pennisetum as a promising candidate species for the phytoextraction of $\mathrm{Cd}$ and $\mathrm{Cu}$ from soils and for tall fescue as a potential $\mathrm{Cd}$-phytostabilizer and $\mathrm{Cu}$-indicator plant in polluted areas. When the solution $\mathrm{Cd} / \mathrm{Cu}$ reached the highest concentration, the plants could not grow normally and the $\mathrm{K} / \mathrm{Na}$ values were dramatically decreased in the roots of pennisetum and tall fescue, except for tall fescue under $\mathrm{Cd}$ stress. Hence, heavy metals could lead to osmotic stress by interrupting the balance between $\mathrm{K}$ and $\mathrm{Na}$ in the roots; moreover, the value of $\mathrm{K} / \mathrm{Na}$ could be considered a reference for measuring the adjustment capacity of plants to heavy metals. Contrary correlations were observed with elements between $\mathrm{Cd}$ and $\mathrm{Cu}$ in pennisetum, indicating that plants use different strategies to regulate $\mathrm{Cd} / \mathrm{Cu}$ absorption by mineral elements. A non-invasive micro-test technique is required to further clarify the relationship between heavy metals and elements.

\section{Acknowledgements}

This research was financially supported by 863 Program (2012AA101802) and the National High-Level Talents Special Support Plan "Ten-thousand Talents Program" (201502510410040).

\section{Conflict of Interest}

The authors declare no conflict of interest.

\section{References}

1. NRIAGU J.O., PACYNA J.M. Quantitative assessment of worldwide contamination of air, water and soils by trace metals. Nature 333, 134, 1988.

2. GARBUIO F.J., HOWARD J.L., dos SANTOS L.M. Impact of human activities on soil contamination. Applied \& Environ Soil Science 2012, 1, 2012.

3. KIRKHAM M.B. Cadmium in plants on polluted soils: Effects of soil factors, hyperaccumulation, and amendments. Geoderma 137, 19, 2006.

4. INMACULADA Y. Copper in plants: acquisition, transport and interactions. Funct. Plant Biol. 36, 409, 2009.

5. WUANA R.A., OKIEIMEN F.E. Heavy Metals in Contaminated Soils: A Review of Sources, Chemistry, 
Risks and Best Available Strategies for Remediation. ISRN Ecology 2011, 2090, 2011.

6. KABATA-PENDIAS A. Trace elements in soils and plants. $4^{\text {th }}$ edn, Boca Raton, 2011.

7. ALI H., KHAN E., SAJAD M.A. Phytoremediation of heavy metals-concepts and applications. Chemosphere 91, 869, 2013.

8. MARQUES A.P.G.C., RANGEL A.O.S.S., CASTRO P.M.L. Remediation of heavy metal contaminated soils: phytoremediation as a potentially promising clean-up technology. Crit. Rev. Env. Sci. Tec. 39, 622, 2009.

9. CUNNINGHAM S.D., OW D.W. Promises and prospects of phytoremediation. Plant Physiol. 110, 715, 1996.

10. RASKIN I., KUMAR P., DUSHENKOV S., SALT D. Bioconcentration of heavy metals by plants. Curr. Opin. Biotech. 5, 285, 1994.

11. BARBOSA B., BOLÉO S., SIDELLA S., COSTA J., DUARTE M.P., MENDES B., CONSENTIN S.L., FERNAND A.L. Phytoremediation of heavy metalcontaminated soils using the perennial energy crops Miscanthus spp. and Arundo donax L. BioEnerg. Res. 8, 1500, 2015.

12. NSANGANWIMANA F., MARCHAND L., DOUAY F. MENCH M. Arundo donax L. a candidate for phytomanaging water and soils contaminated by trace elements and producing plant-based feedstock. a review. Int. J. Phytoremediat. 16, 982, 2014.

13. VALIPOUR A., AHN Y.H. Constructed wetlands as sustainable ecotechnologies in decentralization practices: a review. Environ. Sci. Pollut. R. 23, 180, 2015.

14. LICHT L.A., ISEBRANDS J.G. Linking phytoremediated pollutant removal to biomass economic opportunities. Biomass Bioenerg. 28, 203, 2005.

15. WITTERS N., MENDELSOHN R.O., VAN SLYCKEN S., WEYENS N., SCHREURS E., MEERS E. Phytoremediation, a sustainable remediation technology? Conclusions from a case study. I: energy production and carbon dioxide abatement. Biomass Bioenerg. 39, 454, 2012.

16. ZHANG X., XIA H., LI Z., ZHUANG P., GAO B. Potential of four forage grasses in remediation of $\mathrm{Cd}$ and Zn contaminated soils. Bioresource Technol. 101, 2063, 2010.

17. ZHANG X., GAO B., XIA H. Effect of cadmium on growth, photosynthesis, mineral nutrition and metal accumulation of bana grass and vetiver grass. Ecotox. Environ. Safe. 106, 102, 2014.

18. HU Z., XIE Y., JIN G., FU J., LI H. Growth responses of two tall fescue cultivars to $\mathrm{Pb}$ stress and their metal accumulation characteristics. Ecotoxicology 24, 563, 2014.

19. MEYER A.K.P., EHIMEN, E.A., HOLMNIELSEN J.B. Bioenergy production from roadside grass: a case study of the feasibility of using roadside grass for biogas production in Denmark. Resour. Conserv. Recy. 93, 124, 2014.

20. XU P., WANG Z. Comparison Study in Cadmium Tolerance and Accumulation in Two Cool-Season Turfgrasses and Solanum nigrum L. Water Air Soil Pollut. 225, 1,2014

21. MARSCHNER P. Mineral nutrition of higher plants, $3^{\text {rd }}$ edn. London, 649, 2012.

22. SARWAR N., SAIFULLAH, MALHI S.S., ZIA M.H., NAEEM A., BIBI S., FARID G. Role of mineral nutrition in minimizing cadmium accumulation by plants. J. Sci. Food Agric. 90, 925, 2010.
23. ZHANG G., FUKAMI M., SEKIMOTO H. Influence of cadmium on mineral concentrations and yield components in wheat genotypes differing in cd tolerance at seedling stage. Field Crop Res. 77, 93, 2002.

24. PEÑARRUBIA L., ANDRÉS-COLÁS N., MORENO J., PUIG S. Regulation of copper transport in Arabidopsis thaliana: a biochemical oscillator? J. Biol. Inorg. chem. 15, 29, 2010.

25. FLOWERS T.J., COLMER T.D. Salinity tolerance in halophytes. New Phycol. 179, 945, 2008.

26. GHNAYA T., SLAMA I., MESSEDI D., GRIGNON C., GHORBEL M.H., ABDELLY C. Effects of $\mathrm{Cd}^{2+}$ on $\mathrm{K}^{+}, \mathrm{Ca}^{2+}$ and $\mathrm{N}$ uptake in two halophytes Sesuvium portulacastrum and Mesembryanthemum crystallinum: consequences on growth. Chemosphere 67, 72, 2007.

27. WALI M., GUNSÈ B., LLUGANY M., CORRALES I., ABDELLY C., POSCHENRIEDER C., GHNAYA T. High salinity helps the halophyte sesuvium portulacastrum in defense against cd toxicity by maintaining redox balance and photosynthesis. Planta 244 (2), 333, 2016.

28. HE J., LI H., LUO J., MA C., LI S., QU L., CAI Y., JIANG X., JANZ D., POLLE A., TYREE M., LUO Z. A transcriptomic network underlies microstructural and physiological responses to cadmium in Populus $x$ canescens. Plant Physiol. 162 (1), 424, 2013.

29. ZOUARI M., ELLOUMI N., BEN AHMED C., DELMAIL D., BEN ROUINA B., BENABDALLAH F., LABROUSSE, P. Exogenous proline enhances growth, mineral uptake, antioxidant defense, and reduces cadmium-induced oxidative damage in young date palm (Phoenix dactylifera, L.). Ecol. Eng. 86, 202, 2016.

30. ZHANG C., GUO J., LEE D.K., ANDERSON E., HUANG $\mathrm{H}$. Growth responses and accumulation of cadmium in switchgrass (Panicum virgatum L.) and prairie cordgrass (Spartinapectinata Link). Rsc Adv. 5, 83700, 2015.

31. MANIKANDAN R., EZHILI N., VENKATACHALAM P. Phosphorus supplementation alleviation of the cadmium-induced toxicity by modulating oxidative stress mechanisms in Vetiver Grass [Chrysopogon Zizanioides (L.) roberty]. J. Environ. Eng. 142, 1, 2016.

32. ARDUINI L., GODBOLD D.L., ONNISA A., STEFANI A. Heavy metals influence mineral nutrition of tree seedlings. Chemosphere, 36, 739, 1998.

33. HU Y., WANG D., WEI L., ZHANG X., SONG B. Bioaccumulation of heavy metals in plant leaves from Yan'an city of the loess plateau, China. Ecotox. Environ Safe. 110, 82, 2014.

34. SHABANI L., SABZALIAN M.R., POUR S.M. Arbuscular mycorrhiza affects nickel translocation and expression of $\mathrm{ABC}$ transporter and metallothionein genes in Festuca arundinacea. Mycorrhiza 26:1, 2015.

35. SIPOS G., SOLTI A., CZECH V., VASHEGYI I., CSEH E., FODOR F. Heavy metal accumulation and tolerance of energy grass (Elymus elongatus subsp. ponticus cv. Szarvasi-1) grown in hydroponic culture. Plant Physiol. Biochem. 68, 96, 2013.

36. LI C., XIAO B., WANG Q., YAO S., WU J. Phytoremediation of $\mathrm{Zn}$ - and $\mathrm{Cr}$-contaminated soil using two promising energy grasses. Water Air Soil Pollut. 225 (7), 1, 2014.

37. JONES D.L., DARAH P.R., KOCHIAN L.V. Critical evaluation of organic acid mediated iron dissolution in the rhizosphere and its potential role in root iron uptake. Plant Soil 180, 57, 1996.

38. FU L., CHEN C., WANG B., ZHOU X., LI S., GUO P., SHEN Z., WANG G., CHEN Y. Differences in Copper 
Absorption and Accumulation between Copper-Exclusion and Copper-Enrichment Plants: A Comparison of Structure and Physiological Responses. Plos One 10(7), e0133424, 2015.

39. KIM D.Y., BOVET L., MAESHIMA M., MARTINOIA E., LEE Y. The ABC transporter AtPDR8 is a cadmium extrusion pump conferring heavy metal resistance. Plant J. 50, 207, 2007.

40. ZHANG X., LIN A., GAO Y., REID R., WONG M., ZHU Y. Arbuscular mycorrhizal colonisation increases copper binding capacity of root cell walls of Oryza sativa L. and reduces copper uptake. Soil Biol. Biochem. 41, 930, 2009.

41. HEMELRAAD J., HOLWERDA D.A., WIJNNE H.J.A., ZANDEE D.I. Effects of cadmium in freshwater clams. i. interaction with essential elements in Anodonta cygnea. Arch. Environ. Contam. Toxicol. 19 (5), 686, 1990.

42. GRATTAN S., GRIEVE C. Salinity-mineral nutrient relations in horticultural crops. Sci. Hortic. 78 (1-4), 127, 1998.

43. GREWAL H.S. Response of wheat to subsoil salinity and temporary water stress at different stage of reproductive phase. Plant Soil 330 (1-2),103, 2010.

44. HAN R.M, LEFÈVRE I., RUAN C.J., QIN P., LUTTS S. $\mathrm{NaCl}$ differently interferes with $\mathrm{Cd}$ and $\mathrm{Zn}$ toxicities in the wetland halophyte species Kosteletzkya virginica (L.) Presl. Plant Growth Regul. 68 (1), 97, 2012.

45. GHNAYA T., NOUAIRI I., SLAMA I., MESSEDI D., GRIGNON C., ABDELLY C., GHORBEL M.H. Cadmium effects on growth and mineral nutrition of two halophytes: Sesuvium portulacastrum and Mesembryanthemum crystallinum. J. Plant Physiol. 162, 1133, 2005.

46. WEIMBERG R. Growth and solute accumulation in 3 -week-old seedlings of agropyron elongatiun, stressed with sodium and potassium salts. Physiol. Plant. 67(2), 129, 2010.
47. KALAI T., KHAMASSI K., SILVA J.A.T.D., GOUIA H., BEN-KAAB L.B. Cadmium and copper stress affect seedling growth and enzymatic activities in germinating barley seeds. Arch. Agron. Soil Sci. 60 (6), 765, 2014.

48. LI X., MA H., JIA P., WANG J., JIA L., ZHANG T., YANG Y., CHEN H., WEI X. Responses of seedling growth and antioxidant activity to excess iron and copper in triticum aestivum, 1. Ecotox. Environ. Safe. 86 (4), 47, 2012.

49. ADEM G.D., ROY S.J., ZHOU M., BOWMAN J., SHABALA S. Evaluating contribution of ionic, osmotic and oxidative stress components towards salinity tolerance in barley. BMC plant biology, 14, 113, 2014.

50. BRZOOSKA M.M., MONIUSZKO-JAKONIUK J. Interactions between cadmium and zinc in the organism. Food Chem. Toxicol. 39, 967, 2001.

51. SIMMONS R.W., PONGSAKUL P., SAIYASITPANICH D., KLINPHOKLAP S. Elevated levels of cadmium and zinc in paddy soils and elevated levels of cadmium in rice grain downstream of a zinc mineralized area in thailand: implications for public health. Environ. Geochem. Health. 27, 501, 2005.

52. DONG J., MAO W., ZHANG G., WU F., CAI Y. Root excretion and plant tolerance to cadmium toxicity-a review. Plant Soil Environ. 53, 193, 2007.

53. DU J., YAN C., LI Z. Phosphorus and cadmium interactions in Kandelia obovata (S. L.) in relation to cadmium tolerance. Environ. Sci. Pollut. Res. 21, 355, 2014.

54. LIU H., ZHANG J., CHRISTIE P., ZHANG F. Influence of iron plaque on uptake and accumulation of $\mathrm{Cd}$ by rice (Oryza sativa L.) seedlings grown in soil. Sci. Total Environ. 394, 361, 2008.

55. ALVA A.K., CHEN E. Effects of external copper concentrations on uptake of trace elements by citrus seedlings. Soil Sci. 159, 59, 1995. 